\title{
PENGENAAN PIDANA DENDA YANG DAPAT DIKONVERSI DENGAN PIDANA KURUNGAN PADA PELAKU ANAK
}

\author{
Kajian Putusan Nomor 29/Pid.Sus-Anak/2017/PN.Trg
}

\section{THE CONVERSION OF IMPOSITIONING CRIMINAL FINES TO CONFINEMENT SANCTION FOR CHILD/JUVENILE OFFENDERS}

\author{
An Analysis of Decision Number 29/Pid.Sus-Anak/2017/PN.Trg \\ Emmilia Rusdiana \\ Fakultas Hukum dan Ilmu Sosial Universitas Negeri Surabaya \\ Kampus Unesa Ketintang Surabaya 60231 \\ Email: emmiliarusdiana@unesa.ac.id
}

Naskah diterima: 5 Desember 2018; revisi: 27 Desember 2019; disetujui 27 Desember 2019

http://dx.doi.org/10.29123/jy.v12i3.364

\begin{abstract}
ABSTRAK
Putusan Nomor 29/Pid.Sus-Anak/2017/PN.Trg menjatuhkan pidana penjara dan denda, dengan ketentuan apabila tidak dibayar, diganti (konversi) dengan pidana kurungan dua bulan. Padahal Pasal 71 ayat (3) Undang-Undang Sistem Peradilan Pidana Anak mensyaratkan pidana denda hanya dapat digantikan dengan pelatihan kerja. Permasalahannya adalah apakah sudah sesuai penjatuhan pidana denda yang dapat dikonversi dengan pidana kurungan dikaitkan dengan asas hukum pidana, asas, dan tujuan pemidanaan anak? Jenis penelitian adalah yuridis normatif. Hasil penelitian membuktikan pengenaan sanksi pada putusan hakim tidak sesuai dengan asas hukum pidana berupa legalitas, subsidiaritas, dan kesamaan. Putusan hakim juga tidak sesuai dengan asas pemidanaan anak terutama perampasan kemerdekaan dan pemidanaan sebagai upaya terakhir, asas penghindaran pembalasan serta asas kepentingan terbaik bagi anak. Putusan ini juga menunjukkan adanya tujuan pemidanaan anak sebagai pembalasan daripada perbaikan, dan orientasi pada tujuan pemidanaan pada anak lebih dikedepankan
\end{abstract}

daripada sanksi pidana itu sendiri. Jadi pelatihan kerja lebih tepat dijadikan pilihan daripada pidana kurungan.

Kata kunci: konversi pidana; asas pemidanaan anak; tujuan pemidanaan anak.

\section{ABSTRACT}

Decision Number 29/Pid.Sus-Anak/2017/PN.Trg has impose a prison sentence and a fine, with the provisions that if it is unpaid, it will be substituted with a twomonth confinement sentence. Article 71 paragraphs (3) the Criminal Justice System for Children requires that the substitution of criminal fine should be job training. The question is to determine wether the conversion of criminal fines with confinement is already in accordance with the principles of law, policies, and the purpose of criminal punishment for children. This type of research is normative juridical. The results of the study need to show that the imposition of sanctions on judges'decision is not following the principles of criminal law in the form of legality, subsidiarity, and equality. The court decision is not under the policy of child punishment, especially 
deprivation of liberty and conviction as a last resort, the principle of avoidance of retaliation, and the principle of the best interests of children. This decision also shows that the purpose of punishing children in revenge rather than reparation, and orientation towards the goal of criminalization of children is more prioritized than criminal sanction itself, so job training is best suited as a choice rather than confinement sanction.

Keywords: criminal conversion; principle of child criminalization; purpose of child criminalization.

\section{PENDAHULUAN}

\section{A. Latar Belakang}

Sistem peradilan pidana anak memiliki kekhususan apabila dibandingkan dengan sistem peradilan pidana pada umumnya, dikarenakan anak merupakan individu yang belum matang untuk berpikir dan bertindak. Oleh karenanya anak wajib mendapatkan penanganan khusus yang berbeda dengan orang dewasa, juga anak sebagai korban yang mengalami kerugian akibat tindak pidana dilindungi oleh hukum, tetapi juga anak yang menjadi pelakunya.

Perlindungan terhadap anak pelaku tindak pidana juga tercermin dalam bentuk sanksi, yakni berdasarkan pada Pasal 71 Undang-Undang Nomor 11 Tahun 2012 tentang Sistem Peradilan Pidana Anak (UU SPPA) menyebutkan jenis sanksi pidana yang dapat diberikan kepada anak, yakni: pidana peringatan, pidana dengan syarat, pelatihan kerja, pembinaan di dalam lembaga, dan penjara.

Sanksi pidana merupakan sanksi yang pengenaannya dibatasi oleh asas ultimum remidium (sanksi terakhir yang dikenakan setelah sanksi-sanksi lain telah diberlakukan). Sementara asas pada penerapan sanksi pidana penjara dengan pelaku anak dikaitkan dengan asas perlindungan hukum, bahwa pidana dengan perampasan kemerdekaan, yang dalam hal ini adalah penjatuhan pidana penjara adalah sebagai pilihan terakhir.
Penjatuhan pidana penjara terdapat pada Putusan Nomor 29/Pid.Sus-Anak/2017/ PN.Trg. mengenai tindak pidana pencabulan. Pada laporan penelitian kemasyarakatan dari pembimbing kemasyarakatan pada pokoknya merekomendasikan agar anak dapat ditempatkan di Lembaga Pembinaan Khusus Anak (LPKA) Samarinda di Tenggarong JI. Imam Bonjol No. 68 Kel. Melayu Kec. Tenggarong Kab. KUKAR, sebagaimana dimaksud dalam Pasal 71 ayat (1) huruf d UU SPPA, dengan pertimbangan:

1. Klien melakukan pencabulan karena ketidaktahuan klien, dan hanya sekedar ingin tahu dan mencoba tentang peragaan film porno yang dilihatnya sesaat;

2. Klien masih muda dapat dibina dalam memulihkan mental sosialnya menjadi Iebih baik;

3. Pidana penjara terhadap anak hanya digunakan sebagai upaya terakhir termuat dalam Pasal 81 huruf (5) UU SPPA bahwa, pembelaan anak terhadap tuntutan pidana yang disampaikan oleh penasihat hukumnya di persidangan secara lisan yang pada pokoknya anak mengakui perbuatannya dan merasa bersalah serta menyesal dan terhadap tuntutan pidana penuntut umum tersebut.

4. Anak dan penasihat hukum menyatakan sependapat dengan tuntutan pidana yang diajukan oleh penuntut umum yang menyatakan anak terbukti bersalah dan dijatuhi pidana di LPKA Samarinda di Tenggarong, karena di sana anak dapat memperbaiki diri dan mendapat bimbingan, pendidikan, maupun keterampilan yang dapat menunjang masa depannya, serta menghindarkan dari pengaruh lingkungan pergaulan yang buruk; dan berdasarkan fakta hukum di persidangan, 
laporan penelitian kemasyarakatan dari pembimbing kemasyarakatan, dan hal-hal yang memberatkan dan meringankan dari perbuatan anak, sifat perbuatan anak masih dapat dibina menjadi lebih baik, maka hakim sependapat dengan rekomendasi dan pembelaan penasihat hukum anak agar anak dipidana dengan pidana penjara dalam LPKA.

Putusan Nomor 29/Pid.Sus-Anak/2017/ PN.Trg dengan terdakwa YT merupakan perkara yang melibatkan anak yang berkonflik dengan hukum. YT telah terbukti secara sah dan meyakinkan bersalah melakukan tindak pidana "Beberapa kali dengan sengaja memaksa anak melakukan perbuatan cabul dengannya," oleh karena perbuatannya tersebut YT dijatuhi pidana penjara selama 1 (satu) tahun 6 (enam) bulan di Lembaga Pembinaan Khusus Anak (LPKA) Samarinda di Tenggarong, dan denda sebesar Rp.60.000.000,- (enam puluh juta rupiah) subsider 2 (dua) bulan kurungan dengan ketentuan apabila tidak dibayar diganti dengan pidana kurungan selama 2 (dua) bulan.

Kejanggalan putusan ini adalah dalam hal penjatuhan sanksi pidana yakni berupa penjara dan denda sebesar Rp.60.000.000,- (enam puluh juta rupiah), dengan ketentuan apabila tidak dibayar diganti (konversi) dengan pidana kurungan 2 bulan. Pengaturan dibayar diganti (konversi) putusan ini mendasarkan pada Pasal 30 Undang-Undang Nomor 1 Tahun 1946 tentang Peraturan Pidana di Indonesia (KUHP), sementara itu tindak pidana dengan pelaku anak telah memiliki ketentuan tersendiri yakni dalam UU SPPA. Dalam Pasal 71 ayat (3) menjelaskan bahwa apabila dalam hukum materiel diancam pidana kumulatif berupa penjara dan denda, pidana denda diganti dengan pelatihan kerja, dan Pasal 71 ini tidak diterapkan pada Putusan Nomor 29/Pid.Sus-Anak/2017/PN.Trg.
Pelaksanaan pelatihan kerja sebagai alternatif pidana masih memerlukan pembahasan tersendiri yang mendalam, sehubungan dengan tujuan pelaksanaan wajib latihan kerja sebagai pengganti pidana denda agar anak mempunyai keterampilan baik untuk dikatakan seorang profesional di bidangnya. Tetapi hal ini yang menyebabkan putusan hakim sebagai langkah awal untuk memenuhi hak terdakwa mendapatkan putusan yang baik, sehingga tulisan ini akan mengetengahkan analisis putusan hakim berdasarkan asas hukum pidana, juga asas serta tujuan pemidanaan anak.

Anak yang berkonflik dengan hukum telah melakukan suatu tindak pidana, namun anak tetap harus dilindungi untuk dapat membina dan memperbaiki masa depan anak agar dapat kembali diterima dalam kehidupan bermasyarakat, serta dapat kembali menjadi tunas harapan bangsa. Mengingat kekhususan yang dimiliki anak, baik dari segi rohani dan jasmani, maupun dari segi pertanggungjawaban pidana atas perilaku dan tindakannya, maka haruslah diusahakan agar pemidanaan terhadap anak terutama pidana perampasan kemerdekaan merupakan upaya terakhir (ultimum remedium) bilamana upaya lain tidak berhasil.

\section{B. Rumusan Masalah}

Permasalahan pada putusan hakim yang memutus dengan memberikan pilihan adanya dibayar diganti (konversi) adalah sebagai berikut:

1. Apakah tepat putusan hakim berupa pengenaan pidana denda yang dapat dikonversi dengan pidana kurungan dikaitkan dengan asas hukum pidana?

2. Apakah penjatuhan pidana denda yang dapat 
dikonversi dengan pidana kurungan pada Putusan Pengadilan Negeri Tenggarong Nomor 29/Pid.Sus-Anak/2017/PN.Trg telah sesuai dengan asas-asas dan tujuan pemidanaan anak?

\section{Tujuan dan Kegunaan}

Tulisan ini bertujuan untuk menganalisis ketepatan putusan yang mengenakan pidana denda yang dapat dikonversi dengan pidana kurungan dikaitkan dengan asas hukum pidana, sekaligus sebagai pembuktian atas kesesuaian Putusan Nomor 29/Pid.Sus-Anak/2017/PN.Trg terhadap asas hukum pidana, asas dan tujuan pemidanaan anak. Di sisi yang lain kajian ini dapat mengarahkan konsep pemidanaan anak yang tepat dan dapat dijadikan pedoman bagi hakim anak.

Kegunaan atas kajian putusan ini adalah untuk mempertimbangkan penerapan norma anak dan hak konstitusional yang dimiliki oleh warga masyarakat. Pemaparan ini diharapkan menjadi masukan dan pembelajaran tersendiri bagi hakim anak dalam memberikan pertimbangan putusan dengan melakukan pemilihan aturan yang tepat, sekaligus mendasarkan pada aspek yang lebih luas lagi yakni asas hukum pidana. Pemenuhan secara seimbang dari sisi asas hukum dan asas dan tujuan pemidanaan anak atas sebuah putusan hakim menunjukkan upaya untuk mengembalikan pelaku kepada masyarakat sesuai amanat konstitusi, sekaligus mengingatkan kembali bahwa putusan hakim sebagai parameter keadilan dalam hukum pidana nasional Indonesia dan pelaksanaannya dalam praktik penegakan hukum.

\section{Tinjauan Pustaka}

Menurut Radbruch, sebagaimana dikutip oleh Rahardjo (2000:19), mengatakan bahwa hukum itu harus memenuhi berbagai karya sebagai nilai dasar dari hukum. Nilai dasar hukum tersebut adalah keadilan, kegunaan, dan kepastian hukum. Sekalipun ketiga-tiganya itu merupakan nilai dasar dari hukum, namun antara mereka terdapat suatu ketegangan, oleh karena ketigatiganya berisi tuntutan yang berlainan, sehingga mempunyai potensi untuk saling bertentangan.

Peranan pengadilan (hakim) dalam mewujudkan kepastian hukum, keadilan, dan kemanfaatan antara lain dapat dilihat dari putusan-putusan yang telah dikenakan. Proses peradilan sangat tergantung pada hakim di pengadilan berkaitan dengan bagaimana hakim melaksanakan tugas dan fungsinya. Peranan hakim sangat mulia dan terhormat dalam masyarakat dan negara. Hakim mempunyai tugas menegakkan kebenaran dan keadilan serta dalam tugasnya wajib selalu menjunjung tinggi hukum. Oleh karena itu, dalam penegakan hukum agar dapat berjalan secara efektif maka diperlukan organ penegak hukum yang memadai (Noormansyah, 2006:10).

Putusan yang ideal adalah putusan yang mengandung aspek kepastian, kemanfaatan, dan keadilan agar pelaku pidana anak jera atas tindak pidana yang telah diperbuat, namun di sisi lain hak-hak sebagai anak tetap terpenuhi serta membuat ketertiban hukum dalam masyarakat sehingga penegakan hukum dalam kehidupan masyarakat dapat terwujud (Sulardi \& Yohana, 2015:258-260).

Asas hukum merupakan pikiran-pikiran yang menuntun, pilihan terhadap kebijakan, prinsip hukum, pandangan manusia dan masyarakat, kerangka harapan masyarakat. Asas-asas hukum yang diterapkan pada kebijakan hukum adalah berlandaskan asas 
legalitas sebagai asas pertama. Perkembangan menunjukkan perlunya satu pemahaman quasi antara pemahaman asas legalitas secara formal dan asas legalitas secara materiel. Mengingat hakikat dari asas legalitas sendiri bertujuan untuk mewujudkan satu kepastian hukum maka setiap perbuatan yang dilarang haruslah disebutkan dengan jelas dan tegas berikut sanksinya di dalam suatu ketentuan hukum (Christianto, 2009:373).

Asas kedua adalah asas subsidiaritas, artinya hukum pidana harus ditempatkan sebagai ultimum remedium (senjata pamungkas) dalam penanggulangan kejahatan yang menggunakan instrumen penal, bukan sebagai primum remedium (senjata utama). Asas lain yang juga mempunyai kedudukan penting, yaitu asas persamaan/ kesamaan. Menurut Servan \& Letrossne (Luthan, 2009:9-10), asas kesamaan bukanlah pernyataan dari aspirasi tentang hukum pidana yang lebih adil, asas kesamaan lebih merupakan suatu keinginan diadakannya sistem hukum pidana yang lebih jelas dan sederhana.

Pedoman umum pemidanaan terhadap anak di Indonesia dalam UU SPPA adalah sebagai berikut:

a. Anak hanya dapat dijatuhi pidana atau dikenai tindakan berdasarkan UU SPPA. Ini mengindikasikan bahwa UU ini merupakan UU yang bersifat khusus dan tidak ada pidana atau tindakan di luar UU ini yang dapat dikenakan kepada anak, misalnya jenis pidana mati, pidana seumur hidup, pidana tutupan sebagaimana diatur pada KUHP.

b. Anak dapat dikenai tindakan dan penuntut umum dapat mengajukannya, namun tidak pada tindak pidana yang diancam pidana penjara paling singkat 7 (tujuh) tahun.

c. Pasal 71 ayat (3) apabila dalam hukum materiel diancam pidana kumulatif berupa penjara dan denda, pidana denda diganti dengan pelatihan kerja.

d. Pasal 71 ayat (4) pidana yang dikenakan, dilarang melanggar harkat martabat anak.

e. Bahwa pidana hanya dikenakan pada anak yang sudah berusia 14 (empat belas) tahun sampai dengan 18 (delapan belas) tahun (Sutatiek, 2013).

Pembahasan mengenai pidana dan pemidanaan diawali dengan pengenaan Pasal 71 UU SPPA menyebutkan jenis-jenis sanksi pidana yang dapat diberikan kepada anak, yakni:

1. Pidana pokok bagi anak, terdiri dari:
a. Pidana peringatan
b. Pidana dengan syarat
1) Pembinaan di luar lembaga
2) Pelayanan masyarakat
3) Pengawasan
c. Pelatihan kerja
d. Pembinaan di dalam lembaga
e. Penjara

2. Pidana tambahan, yang terdiri dari:

a. Perampasan keuntungan yang diperoleh dari tindak pidana; dan

b. Pemenuhan kewajiban adat.

3. Apabila dalam hukum materiel diancam pidana kumulatif berupa penjara dan denda, pidana denda diganti dengan pelatihan kerja.

Pidana denda menurut Pasal 30 KUHP, minimum pidana denda adalah Rp.25,- (dua puluh lima rupiah), namun maksimumnya tidak ditentukan secara umum tetapi ditentukan dalam pasal-pasal dari tindak pidana yang bersangkutan. Pidana denda itu dapat dijumpai di dalam Buku ke-I dan Buku ke-II KUHP, yang telah diancamkan baik bagi kejahatan-kejahatan maupun pelanggaran-pelanggaran. Pidana denda tersebut telah diancamkan di dalam KUHP, baik sebagai satu-satunya pidana pokok, maupun secara alternatif, baik dengan pidana penjara saja 
maupun dengan pidana kurungan saja ataupun secara alternatif dengan kedua jenis pidanapidana pokok tersebut secara bersama-sama (BPHN, 2010:19).

Pidana kurungan seperti halnya pidana penjara, merupakan bentuk dari pidana perampasan kemerdekaan bagi terpidana. Di mana terpidana dipisahkan dari pergaulan hidup masyarakat dengan menempatkannya di dalam sebuah lembaga pemasyarakatan dalam waktu tertentu. Pidana kurungan itu minimal satu hari dan maksimal satu tahun; dan dalam hal gabungan kejahatan, residive (pengulangan kejahatan); ketentuan yang terdapat dalam Pasal 52 dan 52a, pidana kurungan menjadi satu tahun empat bulan sesuai dengan yang tertera dalam Pasal 18 ayat (2) KUHP.

Orang-orang yang menjalankan pidana kurungan memiliki beberapa keistimewaan kemudahan di dalam lembaga pemasyarakatan dibandingkan orang-orang yang menjalankan pidana penjara. Sementara pidana kurungan sebagai pengganti pidana denda itu tidak dengan sendirinya harus dijalankan apabila terpidana tidak membayar uang dendanya, yaitu apabila hakim dalam putusannya hanya mengenakan pidana denda saja tanpa menyebutkan bahwa terpidana harus menjalankan pidana kurungan sebagai pengganti dari pidana denda yang telah dikenakan, dalam hal terpidana tidak membayar uang denda yang bersangkutan. Agar seseorang terpidana yang telah dijatuhi pidana denda kemudian dapat diwajibkan untuk menjalankan pidana kurungan, dalam hal ia telah tidak membayar uang denda yang telah ditetapkan oleh hakim, maka di dalam putusan hakim itu secara tegas harus diputuskan tentang besarnya uang denda yang harus dibayar oleh terpidana, dan tentang lamanya pidana kurungan pengganti pidana denda yang harus dijalankan oleh terpidana, yakni dalam hal ia telah tidak membayar lunas uang denda yang bersangkutan (Lamintang, 2010:11).

Pembahasan mengenai anak harus dilihat pada aspek yang lebih luas lagi yakni mengenai asas-asas pemidanaan anak. Dalam Konvensi Hak Anak yang kemudian diadopsi dalam UU PA, ada empat prinsip umum perlindungan anak yang menjadi dasar dalam menyelenggarakan perlindungan anak yaitu:
a. Prinsip non-diskriminasi
b. Prinsip kepentingan yang terbaik bagi anak (best interests of the child)
c. Prinsip hak hidup, kelangsungan hidup, dan perkembangan (the right to life, survival, and development)
d. Penghargaan terhadap pendapat anak (respect for the views of the child) (Djamil, 2013:58)

Asas-asas pemidanaan lain terdapat dalam Pasal 2 UU SPPA bahwa perlindungan terhadap anak yang berhadapan dengan hukum juga tercermin pada asas-asas dalam sistem peradilan pidana anak yang diatur pada UU SPPA, yang berbunyi sistem peradilan pidana anak dilaksanakan berdasarkan asas:
a. Asas perlindungan, meliputi kegiatan yang besifat langsung dan tidak langsung dari tindakan yang membahayakan anak secara fisik dan/atau psikis.

b. Asas keadilan, bahwa setiap penyelesaian perkara anak harus mencerminkan rasa keadilan bagi anak dan tidak boleh melanggar hak dari anak tersebut.

c. Asas non-diskriminasi, adalah tidak adanya perlakuan yang berbeda pada suku, agama, ras, golongan, jenis kelamin, etnik, budaya dan bahasa, status hukum anak, urutan kelahiran anak, serta kondisi fisik dan/mental anak.

d. Asas kepentingan terbaik bagi anak adalah segala pengambilan keputusan 
harus selalu mempertimbangkan kelangsungan hidup dan tumbuh kembang anak.

e. Asas penghargaan terhadap pendapat anak, adalah penghormatan atas hak anak untuk berpatisipasi dan menyuarakan pendapatnya dalam pengambilan keputusan, terutamajika menyangkut hal yang memengaruhi kehidupan anak.

f. Asas kelangsungan hidup dan tumbuh kembang anak, adalah hak asasi yang paling mendasar bagi anak yang dilindungi oleh semua pihak baik negara, pemerintah, masyarakat, keluarga maupun orang tua.

g. Asas pembinaan dan pembimbingan anak, pembinaan adalah kegiatan untuk meningkatkan kualitas, ketakwaan kepada Tuhan Yang Maha Esa, intelektual, sikap dan perilaku, pelatiham ketrampilan, serta kesehatan jasmani dan rohani anak baik di dalam maupun di luar proses peradilan pidana. Sedangkan yang dimaksud pembimbingan adalah pemberian tuntunan untuk meningkatkan kualitas ketakwaan kepada Tuhan Yang Maha Esa, intelektual, sikap dan perilaku, pelatihan ketrampilan, serta kesehatan jasmani dan rohani klien pemasyarakatan.

h. Asas proporsional, adalah segala perlakuan terhadap anak harus memperhatikan batas keperluan, umur, dan kondisi anak.

i. Asas perampasan kemerdekaan merupakan upaya terakhir, adalah pada dasarnya anak tidak dapat dirampas kemerdekaannya, kecuali terpaksa guna kepentingan penyelesaian perkara anak.

j. Asas penghindaran pembalasan, yakni prinsip untuk menjauhkan upaya pembalasan dalam proses peradilan pidana anak.

Selain asas pemidanaan anak, terdapat tujuan pemidanaan anak sehingga pengaturan anak merupakan bagian atas penerapan asas lex specialis derogat legi generalis atas pengaturan pada KUHP. Bahwa dalam sejarah perkembangan hukum pidana, terdapat tiga macam teori yang mengemukakan tujuan pemidanaan, yaitu sebagai berikut:

\section{Teori Absolut atau Teori Pembalasan.}

Pangkal penjatuhan pidana adalah pada pembalasan yang diberikan kepada penjahat, sehingga siapa saja yang berbuat jahat harus dipidana tanpa melihat akibat-akibat apa saja yang dapat timbul karena penjatuhan pidana (Sutatiek, 2013:26). Faktor yang dipertimbangkan hanya masa lalu pelaku tindak pidana, tidak melihat masa depan terpidana.

Tujuan pemidanaan adalah membalas penjahat dengan pidana yang setimpal dengan perbuatannya. Jadi pidana di sini dimaksudkan murni untuk memberikan penderitaan kepada pelaku kejahatan atau tindak pidana. Di samping pidana adalah alat untuk mencapai tujuan pembalasan, pidana juga menuntut adanya keadilan, sehingga dengan pidana itu dimaksudkan agar masyarakat dapat merasakan keadilan dikarenakan yang jahat harus dihukum.

Pembalasan memiliki dua sudut (Setiady, 2010:21) yakni: sudut subjektif (subjectieve vergelding) di mana pembalasan ditujukan pada orang lain yang berbuat salah, dan sudut objektif (objectieve vergelding). V.O.S. memberikan contoh pembalasan objektif, di mana dua orang pelaku yang seorang menciptakan akibat yang lebih serius dari yang lain dan akan dipidana lebih berat.

\section{Teori Relatif atau Teori Tujuan Pidana}

Teori relative atau teori tujuan pidana bukan untuk melakukan pembalasan kepada penjahat 
saja, tetapi terdapat tujuan-tujuan tertentu yang bermanfaat. Dengan demikian, pemberian pidana tidak hanya dilihat dari masa lampau melainkan juga ke masa depan. Oleh karenanya tidaklah semata-mata adanya kejahatan saja melainkan harus dipertimbangkan manfaat pidananya. Memidana bukanlah untuk memuaskan tuntutan absolut dari keadilan semata, namun harus terdapat tujuan lebih jauh daripada hanya mengenakan pidana saja.

Tujuan pidana selain untuk menenteramkan masyarakat yang tidak tenang akibat adanya kejahatan di sekitar mereka, tetapi juga untuk mencegahkejahatan.Pencegahanumum(generale preventie). Pidana dapat mencegah setiap orang agar tidak melakukan kejahatan melalui ancaman pidananya, sebab ancaman pidana mempunyai daya paksa, dengan diancamnya suatu perbuatan dengan sanksi pidana akan memaksa seseorang untuk tidak melakukan perbuatan tersebut. Dan pencegahan khusus (speciale preventie), bahwa pidana dimaksudkan agar terpidana yang pernah melakukan kejahatan, tidak mengulanginya lagi.

Pihak yang mendapat pengaruh langsung dari penjatuhan pidana (pemidanaan) adalah terpidana. Pidana tersebut belum dirasakan secara nyata oleh si terpidana ketika putusan baru dikenakan, baru dirasakan saat sudah dilaksanakan secara efektif, dengan pidana di sini dikehendaki agar terpidana tidak melakukan tindak pidana lagi.

Untuk mencapai maksud dan tujuan tersebut dapat dilakukan dengan memperbaiki penjahat. Adapun caranya ialah dengan memberikan pendidikan berupa tata tertib dan disiplin, serta pendidikan keahlian kepada penjahat selama menjalani pidananya untuk bekal kelak apabila mereka kembali dalam kehidupan bermasyarakat.

\section{Teori Integratif atau Teori Gabungan}

Pertama kali yang mengajukan teori gabungan ini adalah Pellegrino Rossi tahun 1787-1848, di mana sekalipun tetap menganggap pembalasan sebagai asas dari pidana bahwa beratnya pidana tidak boleh melampaui suatu pembalasan yang adil, namun dia berpendirian bahwa pidana mempunyai berbagai pengaruh antara lain perbaikan sesuatu yang rusak dalam masyarakat. Jadi, dasar pembenaran terletak pada kejahatannya ataupun terletak pada tujuan pidananya.

Teori gabungan dibagi ke dalam tiga golongan (Sutatiek, 2013:21-22), yaitu: pertama, teori gabungan dengan menitikberatkan pada pembalasan, tetapi tidak boleh melebihi daripada yang diperlukan dalam mempertahankan ketertiban masyarakat. Penganutnya antara lain PompedanZevenBergen. Pompemenitikberatkan pidana pada pembalasan, tetapi tindak pidana itu harus pula bermaksud mempertahankan ketertiban masyarakat agar kepentingan umum dapat diselamatkan. Zeven Bergen berpendapat bahwa makna tiap pidana adalah pembalasan, tetapi pidana itu bermaksud untuk melindungi ketertiban hukum, mengembalikan hormat kepada hukum dan pemerintah.

$$
\text { Kedua, teori gabungan yang }
$$
menitikberatkan kepada pertahanan ketertiban masyarakat. Menurut teori ini tujuan pemidanaan adalah mempertahankan tata tertib masyarakat, namun penderitaan yang dikenakan tidak boleh lebih berat daripada perbuatan yang dilakukan oleh terpidana. Ketiga, dan teori gabungan yang menitikberatkan yang sama antara pembalasan dengan perlindungan masyarakat. Sehingga dengan konsep gabungan ini maka teori integratif menganggap pemidanaan sebagai 
unsur penjeraan dibenarkan, tetapi tidak mutlak dan harus memiliki tujuan untuk membuat si terpidana dapat berbuat baik di kemudian hari.

Pemidanaan terhadap anak bertujuan untuk: (a) Mencegah perilaku anak yang lebih buruk di kemudian hari, sehingga menjadi manusia yang baik dan berguna; (b) Memberikan perawatan dan perlindungan untuk keselamatan, kesejahteraan dan kesehatan bagi anak; (c) Membebaskan rasa bersalah serta menghapuskan stigma buruk pada anak; dan (d) Menciptakan kondisi lingkungan yang baik bagi tumbuh kembangnya jiwa anak, untuk meningkatkan taraf hidup yang baik bagi pengembangan fisik, mental dan sosialnya.

Tujuan pemidanaan secara umum memiliki tujuan ganda (Effendi, 2011:2), yaitu: (a) Tujuan perlindunganmasyarakat, untukmerehabilitasidan meresosialisasikan si terpidana, mengembalikan keseimbangan yang terganggu akibat tindak pidana, sehingga konflik yang ada dapat selesai; dan (2) Tujuan yang bersifat spiritual Pancasila, yaitu bahwa pemidanaan tidak diperbolehkan merendahkan martabat kemanusiaan.

\section{METODE}

Kajian terhadap Putusan Nomor 29/Pid. Sus-Anak/2017/PN.Trg ini menggunakan metode penelitian yuridis normatif, dengan pendekatan perundang-undangan yang dilakukan dengan menelaah semua peraturan perundang-undangan dan regulasi, dan pendekatan kasus dilakukan dengan menelaah kasus terkait dengan isu yang dihadapi, dan telah menjadi putusan yang mempunyai kekuatan hukum tetap (Amiruddin et al., 2016:19). Sumber-sumber penelitian yang berupa bahan-bahan hukum primer dan bahanbahan hukum sekunder (Marzuki, 2016:133). Bahan hukum primer terdiri dari perundang- undangan, catatan-catatan resmi atau risalah dalam pembuatan perundang-undangan dan putusan hakim (Marzuki, 2013:114).

Bahan hukum primer yang digunakan adalah Undang-Undang Nomor 1 Tahun 1946 tentang Peraturan Pidana di Indonesia (KUHP), Undang-Undang Nomor 8 Tahun 1981 tentang Hukum Acara Pidana (KUHAP), Undang-Undang Nomor 11 Tahun 2012 tentang Sistem Peradilan Pidana Anak (UU SPPA), Undang-Undang Nomor 35 Tahun 2014 tentang Perubahan Atas Undang-Undang Nomor 23 Tahun 2002 tentang Perlindungan Anak, Undang-Undang Nomor 48 Tahun 2009 tentang Kekuasaan Kehakiman serta Putusan Nomor 29/Pid.Sus-Anak/2017/ PN.Trg, yakni sebagai sumber sekaligus acuan pemahaman penelitian. Bahan hukum sekunder berupa literatur atau buku-buku yang ditulis oleh para ahli hukum pidana, hasil-hasil penelitian, artikel, jurnal penelitian hukum sejenis, dan sumber lainnya, serta bahan non-hukum yakni Kamus Besar Bahasa Indonesia (KBBI).

Teknik pengumpulan bahan hukum adalah dengan menggunakan studi kepustakaan dengan cara membaca, mengumpulkan, mempelajari, membuat catatan dan kutipan-kutipan, serta menelaah bahan-bahan pustaka yang berkaitan dengan isu hukum. Teknik pengolahan bahan hukum diolah secara sistematis dengan cara melakukan seleksi bahan hukum yang ada, kemudian melakukan klasifikasi dan menyusun data hasil penelitian tersebut secara sistematis, tentu saja hal tersebut dilakukan secara logis dan teknik analisis bahan hukum dengan menggunakan metode preskriptif. Dalam bidang keilmuan hukum, penelitian yang bersifat normatif adalah berusaha untuk mengkaji dan mendalami serta mencari jawaban apa yang seharusnya dari setiap permasalahan. 
III. HASIL DAN PEMBAHASAN

A. Ketepatan Putusan Nomor 29/Pid.SusAnak/2017/PN.Trg dengan Asas Hukum Pidana

\section{Kajian Diktum Putusan dengan Asas Kepastian Hukum}

Putusan Nomor 29/Pid.Sus-Anak/2017/ PN.Trg, anak didakwa oleh penuntut umum dengan Pasal 76 E jo. Pasal 82 ayat (1) UU Nomor 35 Tahun 2014 tentang Perubahan Atas Undang-Undang Nomor 23 Tahun 2002 tentang Perlindungan Anak jo. Pasal 65 ayat (1) KUHP. Pada diktum putusannya, hakim mengenakan pidana kepada terdakwa dengan pidana penjara selama satu (1) tahun enam (6) bulan di Lembaga Pembinaan Khusus Anak Samarinda di Tenggarong dan denda sebesar Rp.60.000.000,(enam puluh juta rupiah) dengan ketentuan apabila tidak dibayar diganti dengan pidana kurungan selama 2 (dua) bulan.

Tindak pidana yang dilakukan oleh terdakwa merupakan tindak pidana yang melanggar ketentuan Pasal 76 E UU PA. Sedangkan sanksi pidana yang dikenakan apabila melanggar ketentuan Pasal 76 E UU PA adalah dipidana dengan penjara paling singkat 5 (lima) tahun dan paling lama 15 (lima belas) tahun dan denda paling banyak Rp.5.000.000.000,- (lima miliar rupiah).

Pasal 10 KUHP mengenai jenis-jenis sanksi pidana yang mengklasifikasikan pidana ke dalam pidana pokok dan pidana tambahan, berbeda dengan jenis-jenis sanksi pidana yang terdapat pada UU SPPA. Menurut Pasal 10 KUHP, urutan pidana dalam Pasal 10 tersebut dibuat menurut beratnya pidana, di mana yang terberat disebut terlebih dahulu. Jenis sanksi pidana mati dan pidana kurungan sebagai pidana pokok dalam
KUHP, bukan lagi jenis sanksi yang dapat diancamkan dalam peradilan pidana anak.

Berdasarkan pada Pasal 30 KUHP maka dapat diinterpretasikan bahwa seseorang yang telah dijatuhi pidana denda itu dapat seketika menjalani pidana kurungan sebagai pengganti pidana denda, tanpa harus menunggu lampaunya waktu untuk membayar denda apabila ia menghendakinya, atau karena terpidana merasa bahwa dirinya tidak akan mampu membayar uang dendanya dalam jangka waktu yang sudah ditetapkan oleh hakim. Terpidana setiap saat dapat membebaskan diri dari kewajiban untuk menjalankan pidana kurungan dengan cara membayar jumlah uang denda yang telah ditetapkan oleh hakim dalam amar putusan. Seandainya uang denda sebagian dibayar dan sebagian tidak, maka pidana kurungan sebagai pengganti pidana denda dikurangi secara seimbang.

Berdasarkan Pasal 103 KUHP, bahwa ketentuan dalam Bab I sampai dengan Bab VIII buku ini juga berlaku bagi perbuatan-perbuatan yang oleh ketentuan perundang-undangan lainnya diancam dengan pidana, kecuali ditentukan lain. Jadi dalam proses penanganan perkaranya selain berpedoman pada KUHP dan KUHAP, hakim wajib mempertimbangkan UU SPPA sebagai dasar untuk menentukan berat ringannya pidana dan jenis pidana yang dikenakan kepada terdakwa.

Keseluruhan peraturan perundangundangan baik KUHP maupun di luar KUHP, merupakan satu kesatuan sistem pemidanaan sebagai ketentuan umum dan sebagai aturan khusus. Sebagai ketentuan umum tentang pemidanaan yang diatur dalam Buku I KUHP, bukan hanya berlaku bagi ketentuan yang ada 
pada buku II dan buku III KUHP saja, melainkan berlaku juga bagi seluruh perundang-undangan pidana diluar KUHP termasuk UU SPPA. Hal tersebut sebagaimana ditegaskan dalam Pasal 103 KUHP, bahwa bab satu sampai dengan bab delapan buku satu KUHP berlaku pula bagi ketentuan lain di luar KUHP sepanjang tidak ditentukan lain (lex specialist derogat legi generalis). Dengan demikian, berkaitan dengan anak yang menjadi pelaku tindak pidana apabila pada UU SPPA terdapat ketentuan yang bertentangan dengan ketentuan KUHP, maka sejak berlakunya UU SPPA yang seharusnya diberlakukan adalah ketentuan pada UU SPPA karena merupakan lex specialis.

Ketentuan mengenai penggantian denda pada UU SPPA tersebut tentu berbeda dengan Pasal 30 KUHP, di mana pada Pasal 30 KUHP disebutkan bahwa jika denda tidak dibayar maka diganti dengan kurungan. Apabila pada UU SPPA terdapat ketentuan yang bertentangan dengan ketentuan KUHP, maka berdasarkan asas hukum preferensi yakni lex specialis derogat legi generalis, jadi sejak berlakunya UU SPPA yang seharusnya diberlakukan adalah ketentuan pada UU SPPA karena merupakan lex specialis atas KUHP yang merupakan lex generalis.

Berdasarkan fakta hukum di persidangan, laporan penelitian kemasyarakatan dari pembimbing kemasyarakatan, dan hal-hal yang memberatkan dan meringankan dari perbuatan anak, sifat perbuatan anak masih dapat dibina menjadi lebih baik. Maka hakim memberikan pidana pada YT dengan dipidana penjara dalam LPKA. YT merupakan seorang anak yang masih berusia 16 (enam belas) tahun saat ia melakukan tindak pidana pencabulan tersebut. Pidana denda pada UU SPPA yang diatur hanyalah apabila dalam hukum materiel diancam pidana kumulatif berupa penjara dan denda, maka pidana denda diganti dengan pelatihan kerja. Putusan Nomor 29/Pid.Sus-Anak/2017/PN.Trg tersebut tidak sesuai dengan ketentuan yang terdapat pada Pasal 71 ayat (3) UU SPPA, di mana hakim seharusnya mengenakan pidana pelatihan kerja untuk menggantikan pidana denda. Bahwa berdasarkan ketentuan sanksi yang diatur pada Pasal 71 ayat (3) UU SPPA, berkaitan dengan pidana yang dikenakan pada tindak pidana dengan ancaman yakni pidana kumulatif berupa penjara dan denda, di mana denda hanya dapat digantikan dengan pelatihan kerja, akan tetapi hakim justru mengenakan pidana kurungan untuk menggantikan denda terdakwa.

Bentuk konkret dari penyimpangan terhadap pasal-pasal mengenai penjatuhan sanksi pidana terhadap anak yang melakukan tindak pidana dan tidak berkesesuaian dengan ketentuan yang terdapat pada UU SPPA, terdapat dalam diktum Putusan Nomor 29/Pid.Sus-Anak/2017/ PN.Trg atas nama terdakwa YT yang diperiksa, diadili, dan diputus oleh hakim Pengadilan Negeri Tenggarong. Pada putusan perkara anak tersebut selain hakim mengenakan pidana penjara, hakim juga mengenakan pidana kurungan sebagai pengganti pidana denda terhadap terdakwa yang masih berusia 16 (enam belas) tahun. Penjatuhan pidana penjara dan pidana kurungan untuk menggantikan pidana denda pada Putusan Nomor 29/Pid.Sus-Anak/2017/PN.Trg tidak sesuai dengan Pasal 64 huruf g UU PA yang mengatur bahwa perlindungan terhadap anak yang berkonflik dengan hukum dilakukan melalui penghindaran dari penangkapan, penahanan atau penjara, kecuali sebagai upaya terakhir dan dalam waktu yang paling singkat.

Pidana denda pada UU SPPA yang diatur hanyalah apabila dalam hukum materiel diancam 
pidana kumulatif berupa penjara dan denda, maka pidana denda diganti dengan pelatihan kerja dan bukan pidana kurungan. Pelatihan kerja adalah pidana yag dikenakan paling singkat 3 (tiga) bulan hingga 1 (satu) tahun di lembaga penyelenggara pelatihan kerja yang sesuai usia anak. Penjelasan Pasal 78 ayat (1) UU SPPA, menyebutkan bahwa yang dimaksud dengan "lembaga yang melaksanakan pelatihan kerja" antara lain balai latihan kerja, lembaga pendidikan vokasi yang dilaksanakan. Misalnya, oleh kementerian yang menyelenggarakan urusan pemerintahan di bidang ketenagakerjaan, pendidikan atau sosial.

Hakim anak sebagai pemutus perkara, perlu memperhatikan sejumlah pertimbangan, baik dari anak, orang tua, pembimbing kemasyarakatan, ahli ilmu tingkah laku dan pihak-pihak lain yang terkait agar putusannya dapat menjamin perlindungan dan kesejahteraan anak (Sutatiek, 2013:29). Hakim dalam memutus perkara anak harus teliti dan cermat khususnya dalam mengenakan sanksi pidana maupun tindakan pada anak. Dalam UU SPPA jenis pidana dan tindakan lebih banyak dibandingkan dengan Undang-Undang Nomor 3 Tahun 1997 tentang Pengadilan Anak, sehingga diharapkan dengan beragamnya sanksi tersebut dapat menghindarkan anak dari pembalasan dengan pidana penjara yang digunakan sebagai upaya terakhir dan dilangsungkan dalam waktu sesingkat-singkatnya. Hal demikian dikarenakan usia anak yang relatif masih muda sehingga masih dapat dibina agar dirinya menjadi pribadi yang lebih baik lagi, juga untuk menghindarkan anak dari pengaruh buruk lembaga pemasyarakatan, serta anak merupakan tunas harapan bangsa yang wajib mendapatkan perlindungan.

Ketentuan sanksi yang diatur pada Pasal 71 ayat (3) UU SPPA berkaitan dengan pidana yang dikenakan pada tindak pidana dengan ancaman pidana kumulatif berupa penjara dan denda, dan pidana denda hanya dapat digantikan dengan pelatihan kerja. Akan tetapi putusan hakim justru mengenakan berdasarkan Pasal 30 KUHP, hal ini menandakan bahwa asas kepastian hukum untuk mendasarkan pada UU SPPA tidak terpenuhi.

\section{Diktum Putusan dengan Asas Hukum Pidana Lain}

Putusan yang baik adalah putusan yang memenuhi kebutuhan teoritis dan praktis. Teoritis isi dan pertimbangan dalam putusan tersebut dapat dipertanggungjawabkan menurut ilmu hukum, dan praktis berarti dapat menyelesaikan persoalan, dirasa benar, adil dapat diterima oleh para pihak. Putusan yang demikian di dalamnya terkandung keadilan, kepastian, dan kemanfaatan (Mustofa, 2013:164).Penjatuhan pidana kurungan sebagai pengganti pidana denda pada perkara anak YT kurang memiliki kemanfaatan pada diri anak, dikarenakan sebelumnya anak telah dijatuhi pidana penjara, di mana pidana penjara maupun pidana kurungan sama-sama merupakan jenis pidana perampasan kemerdekaan pada diri anak yang membatasi kebebasan anak.

Pengaruh yang terdapat pada tempat di mana anak menjalankan pidananya dan tidak boleh berbaur dengan kehidupan masyarakat maupun dipisahkan dari keluarga yang dimilikinya, tidak sepenuhnya berdampak positif pada psikologi anak dan tumbuh kembang anak, sehingga perampasan kemerdekaan pada anak hendaknya dilakukan dalam waktu yang singkat dan digunakan sebagai upaya terakhir. Sanksi yang diberikan akan lebih bermanfaat pada terdakwa apabila pidana pelatihan kerja yang digunakan untuk menggantikan pidana dendanya. Dengan adanya pelatihan kerja akan mendidik anak yang 
bersangkutan agar memiliki keterampilan yang bermanfaat bagi dirinya karena pelatihan kerja tersebut dilaksanakan di balai latihan kerja dan lembaga pendidikan vokasi. Misalnya, oleh kementerian yang menyelenggarakan urusan pemerintahan di bidang ketenagakerjaan, pendidikan atau sosial.

Perbandingan dengan hasil penelitian lain mengenai pertimbangan Putusan Pengadilan Negeri Niaga Jakarta Pusat Nomor 48/Pailit/2012/ PN-Niaga.Jkt.Pst, meskipun putusan ini direvisi oleh Putusan MahkamahAgung Nomor 704K/Pdt. Sus/2012 bahwa kepastian hukum, keadilan, dan kemanfaatan tidak dilaksanakan secara harmonis dan seimbang. Kepastian hukum nampak lebih dikedepankan dibandingkan keadilan dan kemanfaatan. Sementara asas kepastian hukum, keadilan, dan kemanfaatan telah mendapatkan pengaturannya secara seimbang (harmonis) dalam Undang-Undang Nomor 37 Tahun 2004 pada pertimbangan putusan pengadilan niaga (hakim) (Wijayanta, 2014:216).

Hasil penelitian serupa memang telah jamak dijumpai adanya putusan hakim yang mengedepankan aspek kepastian hukum saja, tetapi Putusan Nomor 219/Pid.Sus-Anak/2017/ PN.Trg ini sama sekali tidak memenuhi semua aspek. Jadi putusan tersebut mengindikasikan sebagai putusan yang tidak ideal karena tidak memenuhi aspek kepastian hukum.

Asas selanjutnya adalah asas subsidiaritas. Asas ini adalah asas yang menyatakan bahwa hukum pidana sebagai ultimum remidium, jadi sebagai sanksi terakhir setelah sanksi-sanksi yang lain dikenakan. Pilihan pidana denda dibayar diganti (dikonversi) dengan pidana kurungan adalah tidak tepat, sebab tidak memenuhi UU SPPA sebagai pilihan terbaik bagi anak, dan menunjukkan bahwa pilihan pidana kurungan sebagai primum remidium dan tidak memberikan alternatif lain. Misalnya mengenai pilihan pemenuhan atas pelaksanaan pidana denda.

Asas kesamaan mengindikasikan adanya sistem hukum pidana yang lebih jelas dan sederhana. Sementara pidana denda dibayar diganti (dikonversi) dengan pidana kurungan menunjukkan bahwa pidana kurungan itu adalah menyebabkan keadaan menjadi lebih kompleks dan menambah beban tambahan buat lembaga pemasyarakatan. Jadi putusan hakim tersebut tidak tepat sebab tidak memenuhi ketiga asas hukum pidana yakni asas legalitas, asas subsidiaritas, dan asas kesamaan.

\section{B. Kajian Putusan Hakim Berdasarkan Asas Pemidanaan Anak}

Putusan hakim berupa dibayar diganti (konversi) pidana kurungan dianalisis dengan asas perlindungan bahwa pelaksanaan pidana kurungan oleh pelaku anak malah menjadi kegiatan yang membahayakan secara fisik dan psikis, terutama terkait dengn pidana atau tindakan yang sesuai dengan kebutuhan anak. Asas keadilan telah diabaikan oleh hakim melalui putusannya, bahwa penyelesaian perkara anak hanya dapat dilakukan berdasarkan UU SPPA sebagai upaya untuk memenuhi hak anak. Begitu juga dengan pemenuhan hak atas implementasi asas non-diskriminasi, adalah status hukum anak dan kondisi fisik dan mental anak.

Asas kepentingan terbaik bagi anak sekaligus asas kelangsungan hidup dan tumbuh kembang anak akan didapat kalau seorang anak berada di luar pengawasan lembaga pemasyarakatan dan bebas menentukan kegiatan sesuai dengan bakat dan minatnya, sehingga lebih 
mensejahterakan anak. Asas ini adalah asas yang mendasar dimiliki seorang anak dan menjadi tanggung jawab semua pihak, baik negara, pemerintah, masyarakat dan keluarga, dan orang tua untuk mewujudkannya.

Prinsip kepentingan yang terbaik bagi anak (best interests of the child) juga diatur pada Konvensi Hak Anak yang kemudian diadopsi dalam UU PA yang menjadi dasar dalam menyelenggarakan perlindungan anak. Prinsip ini mengingatkan kepada semua penyelenggara perlindungan anak bahwa pertimbangan dalam pengambilan keputusan yang menyangkut masa depan anak, kepentingan yang terbaik bagi anak harus menjadi pertimbangan utama dikarenakan masa depan anaklah yang paling terpengaruh oleh dampak adanya suatu pengambilan kebijakan pemerintah, termasuk pula pada putusan pemidanaan yang dikenakan oleh hakim terhadap anak yang nantinya akan memengaruhi kondisi anak setelah dikenakannya pemidanaan tersebut.

Berdasarkan asas pembinaan dan pembimbingan anak, maka anak memerlukan pembina dan pembimbing yang efektif. Anak memiliki penanggung jawab utama yakni orang tua, sehingga pidana kurungan akan menyebabkan pembinaan dan pembimbingan akan tidak efektif dan jauh dari harapan. Kemudian asas proporsional adalah asas yang menunjukkan bahwa pidana kurungan tidak memiliki tujuan yang jelas untuk perbaikan bagi anak, sehingga pidana kurungan memiliki tujuan yang lebih buruk daripada pidana denda.

Asas perampasan kemerdekaan sebagai upaya yang terakhir memiliki makna yang hampir sama dengan asas ultimum remidium, bahwa pidana kurungan yang merupakan bagian dari perampasan kemerdekaan adalah pilihan yang terakhir setelah pilihan-pilihan lain yang lebih diutamakan. Sementara asas penghindaran pembalasan adalah asas yang menjauhkan pembalasan pada proses penyelesaian tindak pidana anak, jadi upaya untuk pemberian sanksi pidana memiliki tujuan untuk memperbaiki pelaku.

Salah satu bentuk pembaharuan yang ada dalam Hukum Pidana Indonesia adalah pengaturan tentang hukum pidana dalam perspektif dan pencapaian keadilan kepada perbaikan, maupun pemulihan keadaan setelah peristiwa dan proses peradilan pidana yang dikenal dengan keadilan restoratif (restoratif justice), jadi dengan pendekatan hubungan pelaku korban atau doer victims relationship.

Diversi dan keadilan restoratif telah diatur UU SPPA dengan lebih mengutamakan perdamaian dari pada proses hukum formal. Pendekatan keadilan restoratif ini melalui sistem diversi. UU SPPA mengatur mengenai kewajiban para penegak hukum mengupayakan diversi (pengalihan penyelesaian perkara anak dari proses peradilan ke proses di luar peradilan pidana) pada seluruh tahapan proses hukum.

Keadilan restoratif dan eksistensi diversi dalam penyelesaian perkara tindak pidana anak untuk mengubah paradigma penghukuman pidana menjadi pemulihan hubungan pelakukorban-masyarakat. Pembahasan diversi dan keadilan restoratif tidak dapat dilakukan dengan lebih mendalam sehubungan dengan dasar pertimbangan dalam putusan hakim. Sebab tindak pidana yang dilakukan tidak memenuhi unsur untuk para penegak hukum menawarkan diversi sesuai dengan Pasal 7 ayat (2) UU SPPA, yakni yang ancaman pidananya adalah di bawah 7 (tujuh) tahun, sedangkan ancaman tindak 
pidana pencabulan adalah 5 (lima) sampai 15 tahun, sehingga tidak memenuhi persyaratan untuk melakukan diversi.

Asas-asas dalam pemidanaan anak juga tidak diterapkan dengan baik oleh hakim dalam memutus perkara anak yakni: asas perlindungan, asas keadilan, asas non-diskriminasi, asas kelangsungan hidup dan tumbuh kembang anak, asas pembinaan dan pembimbingan anak, asas proporsional, asas perampasan kemerdekaan dan pemidanaan sebagai upaya terakhir, asas penghindaran pembalasan, serta memperhatikan Pasal 18 UU SPPA yang berkaitan dengan wajib diperhatikannya kepentingan terbaik bagi anak dalam menangani perkara tindak pidana anak.

\section{Kajian Pertimbangan Hakim \\ Berdasarkan Tujuan Pemidanaan Anak}

Terdakwa didakwa telah melakukan tindak pidana pencabulan. Perbuatan cabul adalah segala macam perbuatan yang melanggar kesopanan atau kesusilaan atau perbuatan keji yang semua ada kaitannya dengan nafsu birahi kelamin, misal cium-ciuman, meraba-raba anggota kemaluan, meraba-raba anggota payudara (persetubuhan juga termasuk dalam pengertian ini) (Annisa, 2017:205). Perbuatan cabul yang dilakukan oleh pelaku menunjukkan bahwa pelaku masih memerlukan didikan dari orang lain termasuk orang tua dan masyarakat, sehingga kajian ini perlu dibahas berdasarkan tujuan pemidanaan.

Berdasarkan teori tujuan pemidanaan, seseorang yang melakukan tindak pidana seharusnya diberikan hukuman (sanksi) yang lebih berkecenderungan untuk memperbaiki pelaku bukan pembalasan belaka (Hamzah, 2016:3). Apalagi dalam hal ini bahwa pelaku tindak pidananya adalah anak yang membutuhkan perlindungan khusus terlebih perlindungan hukum dalam proses peradilannya.

Putusan hakim ini belum sepenuhnya mempertimbangkan mengenai tujuan pemidanaan, apalagi objek yang dijatuhi pidana adalah anak yang usianya masih 16 (enam belas) tahun. Anak yang berkonflik dengan hukum seharusnya dihindarkan dari pembalasan, sehingga penjatuhan pidana bukan hanya bertujuan untuk membalas perbuatan anak saja, tetapi juga terdapat tujuan untuk perbaikan terhadap diri anak.

Memidana bukanlah untuk memuaskan tuntutan absolut dari keadilan semata, namun harus terdapat tujuan lebih baik daripada hanya mengenakan pidana saja. Pemberian pidana tidak hanya terbatas pada kejahatan yang dilakukan oleh si terpidana saja, melainkan juga harus dipertimbangkan mengenai sikap batin pembuat tindak pidana, sikap dan tindakan pembuat sesudah melakukan tindak pidana, riwayat hidup dan keadaan sosial dan ekonomi pelaku tindak pidana, serta pengaruh pidana terhadap masa depan pembuat tindak pidana.

Proses peradilan pidana pada anak wajib mendapatkan perlindungan khusus, terlebih lagi perlindungan hukum sesuai yang diatur pada UU PA dan UU SPPA. Tidak tepat apabila tujuan pemidanaan terhadap anak disamakan dengan tujuan pemidanaan terhadap orang dewasa pada umumnya. Anak merupakan individu yang dalam tingkah laku dan perbuatannya memiliki karakteristik yang berbeda dengan pelaku tindak pidana orang dewasa. Anak merupakan individu yang belum matang untuk berpikir dan bertindak sehingga wajib memperoleh penanganan khusus yang berbeda dari orang dewasa.

Berkaitan dengan penjatuhan sanksi terhadap anak, tujuan yang hendak dicapai adalah 
perlindungan hukum yang harus mengedepankan yang terbaik bagi kepentingan anak, sehingga dapat tercapainya kesejahteraan anak (Sambas, 2010:60). Pertimbangan mengenai berat ringannya sanksi tidak sebatas hanya mengenai pengurangan dari ancaman sanksi untuk orang dewasa, tetapi juga memerlukan pertimbangan bobot sanksi yang dikenakan. Anak yang berkonflik dengan hukum seharusnya dihindarkan dari pembalasan, sehingga penjatuhan pidana bukan hanya bertujuan untuk membalas perbuatan anak saja, tetapi juga terdapat tujuan untuk perbaikan terhadap diri anak.

Pemidanaan terhadap anak bertujuan untuk mencegah perilaku anak yang lebih buruk di kemudian hari, memberikan perawatan dan perlindungan untuk keselamatan, kesejahteraan dan kesehatan bagi anak, membebaskan rasa bersalah serta menghapuskan stigma buruk pada anak, menciptakan kondisi lingkungan yang baik bagi tumbuh kembangnya jiwa anak, untuk meningkatkan taraf hidup yang baik bagi pengembangan fisik, mental dan sosialnya. Kesemua hal di atas tersebut hanya dapat dipenuhi manakala anak tidak menjalani pidana kurungan dan tentu saja pidana denda akan lebih baik demi tujuan pemidanaan anak.

Tujuan pemidanaan yang utama adalah memberikan perlindungan masyarakat dengan merehabilitasi si terpidana, dan hal ini adalah tidak tepat untuk pemidanaan anak, juga upaya untuk merendahkan martabat kemanusiaan. Padahal salah satu pencegahan atas hal ini adalah menghindari munculnya labelling pada mantan narapidana apabila telah menjalani pidana kurungan/penjara. Penjatuhan pidana (pemidanaan) terhadap anak juga wajib memperhatikan kepentingan terbaik bagi anak, sehingga nantinya pemidanaan tersebut akan memberikan manfaat untuk memperbaiki pelaku tindak pidana agar dapat diterima kembali dalam kehidupan bermasyarakat. Apalagi dalam hal ini yang menjadi objek pemidanaan adalah seorang anak yang dalam setiap proses penyelesaian perkaranya kepentingan yang terbaik bagi anak harus diperhatikan.

Sanksiyang diberikan akanlebihbermanfaat pada terdakwa apabila pidana pelatihan kerjalah yang digunakan untuk menggantikan pidana denda yang dikenakan, karena pelatihan kerja akan mendidik anak yang bersangkutan agar memiliki keterampilan yang bermanfaat bagi dirinya, di mana pelatihan kerja tersebut dilaksanakan di balai latihan kerja dan lembaga pendidikan vokasi. Misalnya oleh kementerian yang menyelenggarakan urusan pemerintahan di bidang ketenagakerjaan, pendidikan atau sosial. Tujuan pemidanaan pada anak seharusnya lebih dikedepankan daripada sanksi pidana itu sendiri, jadi tujuan pemidanan untuk memperbaiki perilaku anak melalui pelatihan kerja daripada pilihan pidana kurungan.

\section{KESIMPULAN}

Berdasarkan hasil pembahasan tesebut maka dapat disimpulkan sebagai berikut:

Putusan hakim ini dinyatakan tidak tepat sebab tidak mendasarkan pada ketentuan sanksi yang diatur pada Pasal 71 ayat (3) UU SPPA. Berarti asas kepastian hukum tidak terpenuhi. Saat ada pilihan pidana kurungan itu menunjukkan adanya asas primum remidium dan tidak memenuhi asas subsidiaritas. Kemudian asas kesamaan tidak terpenuhi saat pidana kurungan lebih kompleks dan menambah beban tambahan dan berkebalikan dengan pelatitan kerja. 
Putusan hakim ini tidak tepat jika disesuaikan dengan asas pemidanaan anak, sebab tidak mempertimbangkan asas perlindungan, asas keadilan, asas non-diskriminasi, asas kelangsungan hidup dan tumbuh kembang anak, asas pembinaan dan pembimbingan anak, asas proporsional, asas perampasan kemerdekaan dan pemidanaan sebagai upaya terakhir, asas penghindaran pembalasan, serta asas kepentingan terbaik bagi anak dalam menangani perkara tindak pidana anak. Begitu juga dengan tujuan pemidanaan putusan ini menunjukkan penjatuhan pidana dengan pembalasan daripada perbaikan bagi anak, dan orientasi pada tujuan pemidanaan pada anak lebih dikedepankan daripada sanksi pidana itu sendiri. Jadi dengan berbagai alasan tersebut membuktikan bahwa pelatihan kerja lebih tepat dikenakan daripada pidana kurungan.

\section{DAFTAR ACUAN}

\section{Buku}

Amiruddin et al. (2016). Pengantar metode penelitian hukum. Edisi revisi. Cetakan ke-9. Jakarta: Rajagrafindo Persada.

Badan Pembinaan Hukum Nasional [BPHN]. (2010). Perencanaan pembangunan hukum nasional bidang hukum pidana \& sistem pemidanaan (Politik hukum \& pemidanaan). Jakarta: Departemen Hukum dan Hak Asasi Manusia Badan Pembinaan Hukum Nasional.

Djamil, M.N. (2013). Anak bukan untuk dihukum; Catatan pembahasan UU Sistem Peradilan Pidana Anak (UU SPPA). Jakarta: Sinar Grafika.

Effendi, E. (2011). Hukum Pidana Indonesia-suatu pengantar. Bandung: Refika Aditama.
Lamintang, P.A.F. (2010). Hukum penitensier Indonesia. Jakarta: Sinar Grafika.

Marzuki, P.M. (2013). Penelitian hukum. Jakarta: Prenada Kencana.

(2016). Penelitian hukum. Edisi Revisi. Jakarta: Prenada Media Group.

Mustofa, W.S. (2013). Kode etik hakim. Jakarta: Prenada Media Group.

Rahardjo, S. (2000). Ilmu hukum. Bandung: PT Citra Aditya Bakti.

Sambas, N. (2010). Pembaruan sistem pemidanaan anak di Indonesia. Yogyakarta: Graha Ilmu.

Setiady, T. (2010). Pokok-pokok hukum penitensier Indonesia. Bandung: Alfabeta.

Sutatiek, S. (2013). Rekonstruksi sistem sanksi. Yogyakarta: Aswaja Pressindo.

\section{$\underline{\text { Jurnal }}$}

Annisa, F. (2017). Penegakan hukum terhadap anak yang melakukan tindak pidana pencabulan dalam konsep restoratif justice. Jurnal Hukum, 7(2), 202-211.

Christianto, H. (2009, Juli-September). Pembaharuan makna asas legalitas. Jurnal Hukum dan Pembangunan, 39(3), 347-375.

Hamzah, H. (2016). Analisis Putusan Pengadilan Negeri Padang Nomor 9/Pid.Sus-Anak/2015/ Pn.Pdg. tentang pemidanaan anak penyalahguna narkotika bagi diri sendiri. Jurnal Novum, 1(2), $1-11$.

Luthan, S. (2009, Januari). Asas \& kriteria kriminalisasi. Jurnal Hukum, 1(16), 1-17.

Noormansyah, D. (2006, Februari). Holding game, merger \& penegakan hukum persaingan usaha. Jurnal Ilmu Hukum Litigasi, 7(1), 10. 
Sulardi \& Yohana, P.W. (2015, Desember). Kepastian hukum, kemanfaatan, \& keadilan terhadap perkara pidana anak. Jurnal Yudisial, 8(3), 251-268.

Wijayanta, T. (2014). Asas kepastian hukum, keadilan \& kemanfaatan dalam kaitannya dengan putusan kepailitan pengadilan niaga. Jurnal Dinamika Hukum, 14(2), 216-226. 